\title{
Curcumin Effect on Bleomycin-Induced Pulmonary Fibrosis in Mus musculus
}

\author{
Rahmi $\mathrm{A}^{1}$, Setiyono $\mathrm{A}^{2}$, Juniantito $\mathrm{V}^{2}$ \\ ${ }^{I}$ Graduate School of Animal Biomedical Science, Faculty of Veterinary Medicine, Bogor Agricultural University \\ ${ }^{2}$ Division of Pathology, Department of Clinic, Reproduction and Pathology, Faculty of Veterinary Medicine, Bogor Agricultural University \\ E-mail: annisarahmi44@gmail.com; vetnizahju@apps.ipb.ac.id
}

(received 31-03-2015; revised 29-05-2015; accepted 04-06-2015)

\begin{abstract}
ABSTRAK
Rahmi A, Setiyono A, Juniantito V. 2015. Pengaruh kurkumin terhadap fibrosis paru-paru akibat aplikasi bleomisin pada Mus musculus. JITV 20(2): 148-157. DOI: http://dx.doi.org/10.14334/jitv.v20i2.1169

Kurkumin merupakan bahan aktif utama dari tanaman kunyit (Curcuma longa) diketahui memiliki aktivitas sebagai antioksidan dan anti-inflamasi. Bleomisin merupakan salah satu obat anti-kanker yang dapat menginduksi fibrosis paru-paru pada manusia dan hewan. Tujuan penelitian ini adalah untuk mengetahui efek biologis kurkumin pada fibrosis paru-paru yang diinduksi bleomisin pada mencit. Sebanyak 16 ekor mencit galur ddy dibagi dalam 4 kelompok perlakuan: (i) kontrol, $100 \mu 1$ aquadest steril diinjeksikan secara SC, (ii) bleomisin (BLM), $100 \mu \mathrm{l}$ bleomisin konsentrasi $1 \mathrm{mg} / \mathrm{ml}$ diinjeksikan secara SC, (iii) kurkumin (CMN), $100 \mu \mathrm{l}$ aquadest steril diinjeksikan secara SC dan $100 \mathrm{mg} / \mathrm{kg}$ BB kurkumin dalam 0,5\% carboxymethylcellulose (CMC) yang diinjeksikan secara IP, dan (iv) BLM+CMN, $100 \mu$ l bleomisin dengan konsentrasi $1 \mathrm{mg} / \mathrm{ml}$ diinjeksikan secara SC dan $100 \mathrm{mg} / \mathrm{kg}$ BB kurkumin dalam 0,5\% CMC diinjeksikan secara IP. Semua perlakuan diberikan setiap hari selama 4 minggu. Organ paru-paru dikoleksi dalam 10\% buffered neutral formalin (BNF). Pengamatan histopatogi dengan pewarnaan hematoksilin-eosin (HE) dan Masson's trichrome (MT) untuk diamati tebal dinding alveol dan luas daerah jaringan ikat. Hasil penelitian menunjukkan bahwa pada kelompok perlakuan bleomisin (BLM) terjadi peningkatan luas jaringan ikat dan tebal dinding alveol secara signifikan jika dibandingkan dengan kontrol. Sementara itu, pemberian kurkumin pada mencit yang mendapatkan induksi bleomisin (kelompok BLM+CMN), menyebabkan terjadinya penurunan signifikan luas jaringan ikat dan tebal dinding alveol. Dapat disimpulkan kurkumin memiliki aktivitas sebagai inhibitor fibrogenesis untuk mengurangi keparahan fibrosis paru-paru akibat aplikasi bleomisin pada mencit.
\end{abstract}

Kata Kunci: Bleomisin, Fibrosis Paru-paru, Mencit, Kurkumin

\begin{abstract}
Rahmi A, Setiyono A, Juniantito V. 2015. Curcumin effect on Bleomycin-induced pulmonary fibrosis in Mus musculus. JITV 20(2): 148-157. DOI: http://dx.doi.org/10.14334/jitv.v20i2.1169

Curcumin, a curcuminoid compound of turmeric has been demonstrated to have anti-oxidant and anti-inflammatory properties. Bleomycin (BLM) is an anti-cancer drug induced pulmonary fibrosis in human and animals. This study was aimed to investigate biological effects of curcumin on bleomycin-induced pulmonary fibrosis in mice (Mus musculus) through pathomorphological assessment. In this study, 16 mice ddy strain were divided into four groups, namely (i) control, mice were subcutaneously (SC) injected with $100 \mu \mathrm{l}$ sterilized aquadest in dorsal skin, (ii) BLM group, injected SC with $100 \mu 1 \mathrm{of} 1 \mathrm{mg} / \mathrm{ml}$ BLM in dorsal skin, (iii) Curcumin (CMN) group, mice were intraperitoneally (IP) injected with $100 \mathrm{mg} / \mathrm{kg}$ body weight (BW) curcumin dissolved in $0,5 \%$ carboxy methyl cellulose (CMC) and injected with $100 \mu$ l sterilized aquadest SC, (iv) BLM+CMN group, injected SC with $100 \mu \mathrm{l}$ of BLM $1 \mathrm{mg} / \mathrm{ml}$ and injected IP with $100 \mathrm{mg} / \mathrm{kg} \mathrm{BW} \mathrm{CMN} \mathrm{in} \mathrm{0,5 \%} \mathrm{CMC.} \mathrm{All} \mathrm{treatments} \mathrm{were}$ performed daily for four weeks period. The lung samples were collected and fixed in buffered neutral formalin (BNF) $10 \%$. Histopathological evaluation was performed with hematoxylin-eosin (HE) and Masson's trichrome (MT) stains. The results showed that BLM treatment significantly increased fibrosis area and alveolar wall area fraction as compared to control. OIn the other hand, CMN treatment significantly reduced fibrosis area and alveolar wall area fraction in mice treated with BLM. In conclusion, our study showed that CMN treatment may inhibit lung fibrogenesis in BLM-induced pulmonary fibrosis.
\end{abstract}

Key Words: Bleomycin, Curcumin, Mice, Pulmonary Fibrosis

\section{INTRODUCTION}

Pulmonary fibrosis is a chronic pulmonary disease characterized by pathological lesions in the form of extracellular matrix and tissues component changes, followed by clinical symptoms, physiological disorders, and radiographic findings (Todd et al. 2012). Many factors cause this pulmonary fibrosis, such as it is exposured by air poison, particular pulmonary disease, effect of radiation therapy and chemotherapy (Ley \& Collard 2013). 
Bleomycin (BLM) is used as a chemotherapy agent for various cancers. This antibiotic of antitumor is a derivative glycopeptide isolated from Streptomyces verticillus (Yamamoto 2010). BLM has strong antitumor activity. Clinically, BLM is used as tumor therapy such as squamous cell carcinoma at around head and neck (including mouth, tongue, tonsils, nasopharynx, oropharynx, sinus, palate, lips, buccal mucosa, the gums, the epiglottis, and larynx), malignant lymphoma, testicular carcinoma, and malignant pleural effusion (Chu et al. 2010).

The main limitation of BLM therapy is its side effect which causes alveolitis fibrosis (Matsushita et al. 2008). Frusch et al. (2012) said that there are several syndromes in the lung linked with BLM utilization, that is bronchiolitis obliterans, hypersensitivity eosinophils, and interstitial pneumonitis which will thrive become pulmonary fibrosis. Besides, BLM-induced pneumonitis can reach $46 \%$ in patients who receive BLM treatment. Mortality level of the pulmonary fibrosis disease is around $10-20 \%$ with $2-3 \%$ from patients treated by BLM. Brugge et al. (2013) said that BLM therapy side effect could cause pneumonitis.

Fibrosis mechanism in lung due to the side effect of BLM utilization has not known. Some factors that have role in pulmonary fibrosis in BLM therapy are oxidative stress, BLM-hydrolase enzyme deactivation, genetic, and the release of inflammatory cytokines (Brugge et al. 2013; Reinert et al. 2013). BLM use in human also causes other side effect, such as an abnormality skin characterizes the scleroderma (Juniantito et al. 2013).

Fibrosis pathogenesis (fibrogenesis) is divided in several overlapping phases, namely inflammation, connective tissue proliferation, and intractable fibrosis (Matsushita et al. 2008; Reinert et al. 2013). Retardation in one step of fibrogenesis causes a decreasing of connective tissue formation (LoomisKing et al. 2013). BLM could stimulate endothelial cells, macrophages, and fibroblasts to induce synthesis of inflammatory mediators especially proinflammatory and fibrogenic cytokines, inducing apoptosis, and free radicals synthesis (Yamamoto 2010; Yamamoto \& Katayana 2011). It was thought that prevention of fibrosis might be mediated by inhibition of inflammation with anti-inflammatory substances (Basnet \& Skalko-Basnet 2011; Kardena \& Winaya 2011).

Curcumin (diferuloylmethane) is an active ingredient in turmeric, in addition, it is also known as an antioxidant (Zhang et al. 2011). Turmeric is widely available plant in Indonesia which is used often as spice and herbal ingredient. Anti inflammation effect of curcumin is likely because of a high pleiotropic molecule which able to interact with and related to the most transcription factors in inflammatory mediators synthesis and inhibiting free radicals releasing in the inflammatory cells (Jurenka 2009; Marçal et al. 2012).

Some studies have been conducted to determine curcumin effect as anti-inflammation and its potential to prevent the fibrosis (Jurenka 2009; Beevers \& Huang 2011; Kardena \& Winaya 2011). Curcumin can decrease fibrosis level in liver, kidney, and lung of laboratory animal (Beevers \& Huang 2011). Therefore, curcumin can be used as potential candidate of antifibrosis preparate, especially in pulmonary fibrosis. This study was aimed to see the curcumin potential in preventing the side effect of BLM use in cancer patients who are undergoing a chemotherapy.

\section{MATERIALS AND METHODS}

\section{Time and place}

This study was conducted during December 2014 March 2015 in Laboratory Animals Management Unit (UPHL), Faculty of Veterinary Medicine, Bogor Agricultural University and Histopathology Laboratory, Pathology Division, Faculty of Veterinary Medicine, Bogor Agricultural University.

\section{Inducer material of pulmonary fibrosis}

Bleocin $^{\circledR}$ (Bleomycin hydrochloride $15 \mathrm{mg}$, Kalbe Farma, Jakarta, Indonesia) was diluted in $15 \mathrm{ml}$ sterile aquadest to reach concentration of $1 \mathrm{mg} / \mathrm{ml}$. As much as $100 \mu \mathrm{L}$ of the solution was injected subcutaneously (SC) on the back skin for BLM and BLM+CMN group everyday for 4 weeks.

\section{Curcumin}

Curcumin active ingredients (Biopurify, Chengdu, China) was diluted in $0.5 \%$ carboxymethylcellulose (CMC) and injected $100 \mathrm{mg} / \mathrm{kg}$ of body weight by intraperitoneal injection (IP) in CMN and BLM+CMN group everyday for 4 weeks.

\section{Experimental procedure}

All of procedures conducted in this study met the requirement of Animal Ethics Commission of Bogor Agricultural University Number 25-2014 IPB. Sixteen 4 weeks old male ddy strain mice with body weight around 20-25 gram (The National Agency of Food and Drug Control (NA-DFC), Jakarta, Indonesia) were used and divided into 4 groups. There were 4 mice in each group.

This study was divided into 4 treatment groups, namely: (i) control, injected subcutaneously by $100 \mu \mathrm{L}$ sterile aquadest in the back skin, (ii) BLM, injected 
subcutaneously in the back skin with $100 \mu \mathrm{L}$ BLM of 1 $\mathrm{mg} / \mathrm{mL}$ concentration, (iii) $\mathrm{CMN}$, injected subcutaneously with $100 \mu \mathrm{L}$ sterile aquadest in the back skin and injected intraperitoneally with curcumin of 100 $\mathrm{mg} / \mathrm{kg}$ of body weight in $0.5 \% \mathrm{CMC}$, and (iv) BLM+CMN, injected subcutaneously with $100 \mu \mathrm{L}$ BLM of $1 \mathrm{mg} / \mathrm{mL}$ concentration and injected intraperitoneally with curcumin of $100 \mathrm{mg} / \mathrm{kg}$ of body weight in $0.5 \% \mathrm{CMC}$. Injection of the curcumin by intraperitoneal injection was adapted from $\mathrm{Li}$ et al. (2013).

This study was done in three steps, namely: (i) acclimatization, the experimental animals were adapted in new cage for 2 weeks, (ii) treatments, the experimental animals were treated in accordance to the respective groups everyday for 4 weeks, (iii) termination, the experimental animal were euthanized by giving Ketamine HCL of $0.2 \mathrm{~mL} /$ head (AVMA 2013). Furthermore, left lobus of lung was collected to be made histopathology preparates, then stained by hematoxylin-eosin (HE) for observation of tissue structure of the lung (Fischer et al. 2006) and Masson'strichrome (MT) to see the presence of connective tissue (Suvik \& Effendy 2012).

\section{Histopathological assesment by HE and MT stains}

Lung of BNF $10 \%$ was sliced in $3 \mathrm{~mm}$ and inserted into tissue cassette for dehydration process, clearing and paraffin infiltration using automatic tissue processor. Chunk organs, further was printed in the paraffin until paraffin block formed. For histology test, the paraffin block was sliced by rotary microtome in 3$5 \mu \mathrm{m}$ of thickness. Cutting results were placed in object glass to be deparafinized and rehydrated for tissue staining by hematoxylin-eosin and Masson's trichrome. All of the cutting results were observed by a light microscope which was connected to the computer. Observed parameters of this organ were connective tissue width and alveoli wall thickness.

\section{Connective tissue width}

Connective tissue width was quantitatively counted by Image $J^{\circledR}$ software (http://imagej.nih.gov//ij/; NIH, Maryland, USA), by analyzing tissue slide which has stained by modification of MT stains (Suvik \& Effendy 2012). Image $J^{\circledR}$ software utilization is to decrease the level of counting subjectivity by scoring method. By using 40x objective lens magnification, as much as 20 visual fields per treatment group randomly selected by video camera (Indomikro ${ }^{\circledR}$ HDMI camera) which was shown on colored screen. The width of each visual field was $326.40 \times 184.00 \mu \mathrm{m}^{2}$. Furthermore, figure was customized for contrast, brightness, and threshold color. Image analysis program detected the width of blue area which indicates collagen area or connective tissue in each visual field and presented in the form of percentage.

\section{Alveolar wall thickness}

Alveoli wall thickness quantitatively was counted by analyzing tissue slide which has been stained by HE. As much as 20 visual fields per treatment group were randomly selected using video camera showed on the colored screen. The wide of each visual field was $326.40 \times 184.00 \mu \mathrm{m}^{2}$. Alveoli wall thick measurement was done 10 times of every visual field, and the data presented in the form of average.

\section{Data analysis}

Percentage of width of connective tissue and alveoli wall thickness were analyzed by $\mathrm{SAS}^{\circledR} 1.9$ software for Microsoft ${ }^{\circledR}$ Windows $^{\circledR}$ ANOVA and presented in form of average and standard deviation. Further, Duncan advance test was done to determine whether there is a significant differences between the treatments or not.

\section{RESULT AND DISCUSSION}

\section{Histology Result by Hematoxylin-Eosin Staining}

Figure 1 is photomicrography of lung tissue of each treatment. Figure 1A is a photomicrography of control group of lung tissue. In this figure, normal alveoli wall structure is $3.7 \pm 0.6 \mu \mathrm{m}$. The same thing occurred in CMN group (Figure 1C). It is shown that lung with normal alveoli wall structure of $3.4 \pm 0.5 \mu \mathrm{m}$.

Figur 1B is a photomicrography of BLM group. In this group, it is shown an inflammation accompanied by an increase in cell number in interstitium, therefore alveoli wall become thicker $(24.9 \pm 6.3 \mu \mathrm{m})$ than the control group. Besides, there was an infiltration of inflammatory cells dominated by macrophages and lymphocytes. Alveoli wall thickening resulted in width of alveoli area became smaller, therefore the air entered the lung became limited. Rienert et al. (2013) said that thickening of the alveoli wall would cause difficulty in breathing (anoxia). In the BLM+CMN group (Figure 1D), it is shown lesion similar to the BLM group, that is the presence of inflammation, increasing in cell number in interstitial and the thickening of the alveoli wall $(9.9 \pm 2.6 \mu \mathrm{m})$ with lower severity compared to the BLM group. 

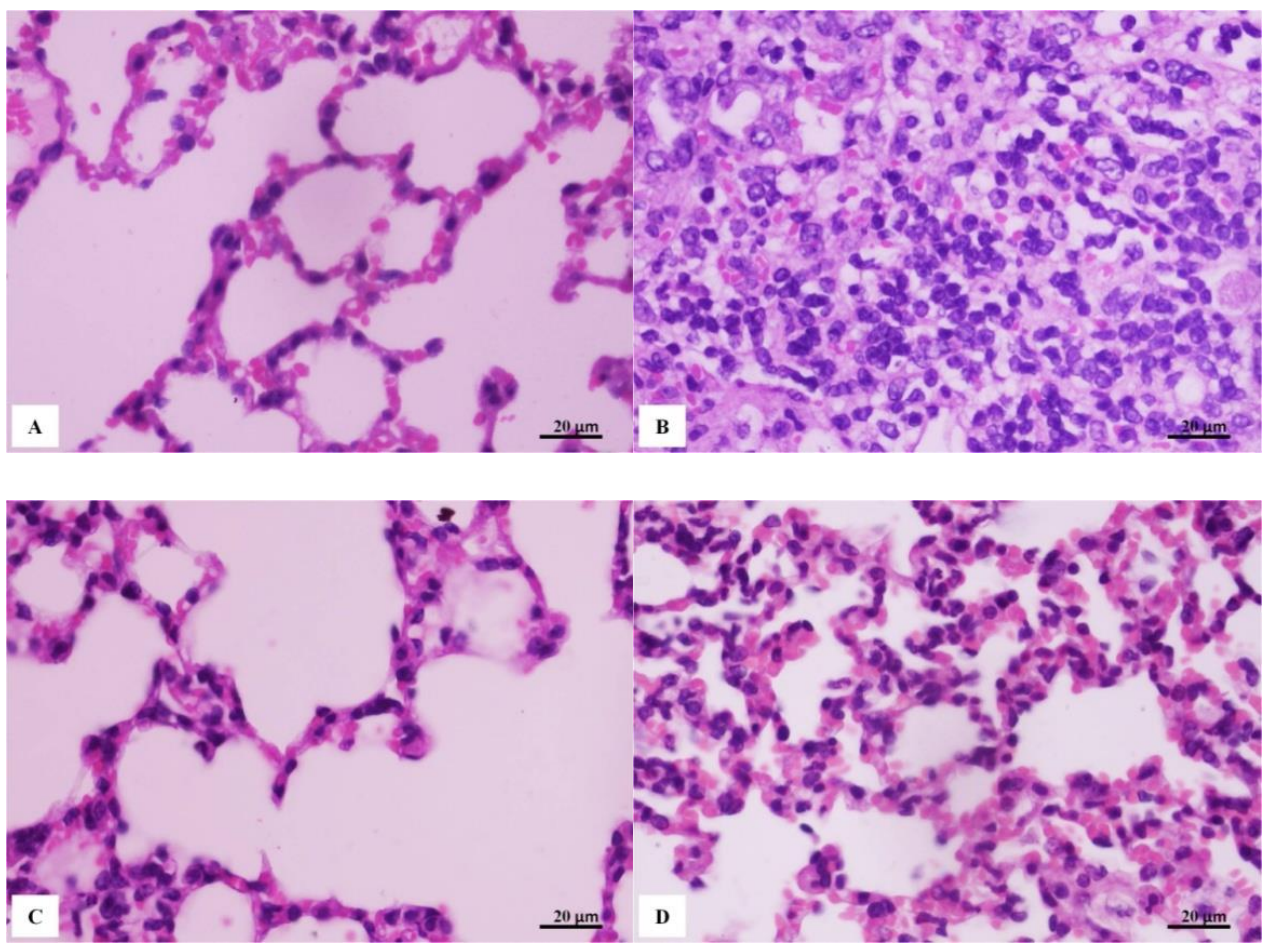

Figure 1. Photomicrography of lung tissues by HE staining of each treatment group: Control (A); BLM (B); CMN (C); and $\mathrm{BLM}+\mathrm{CMN}(\mathrm{D})$
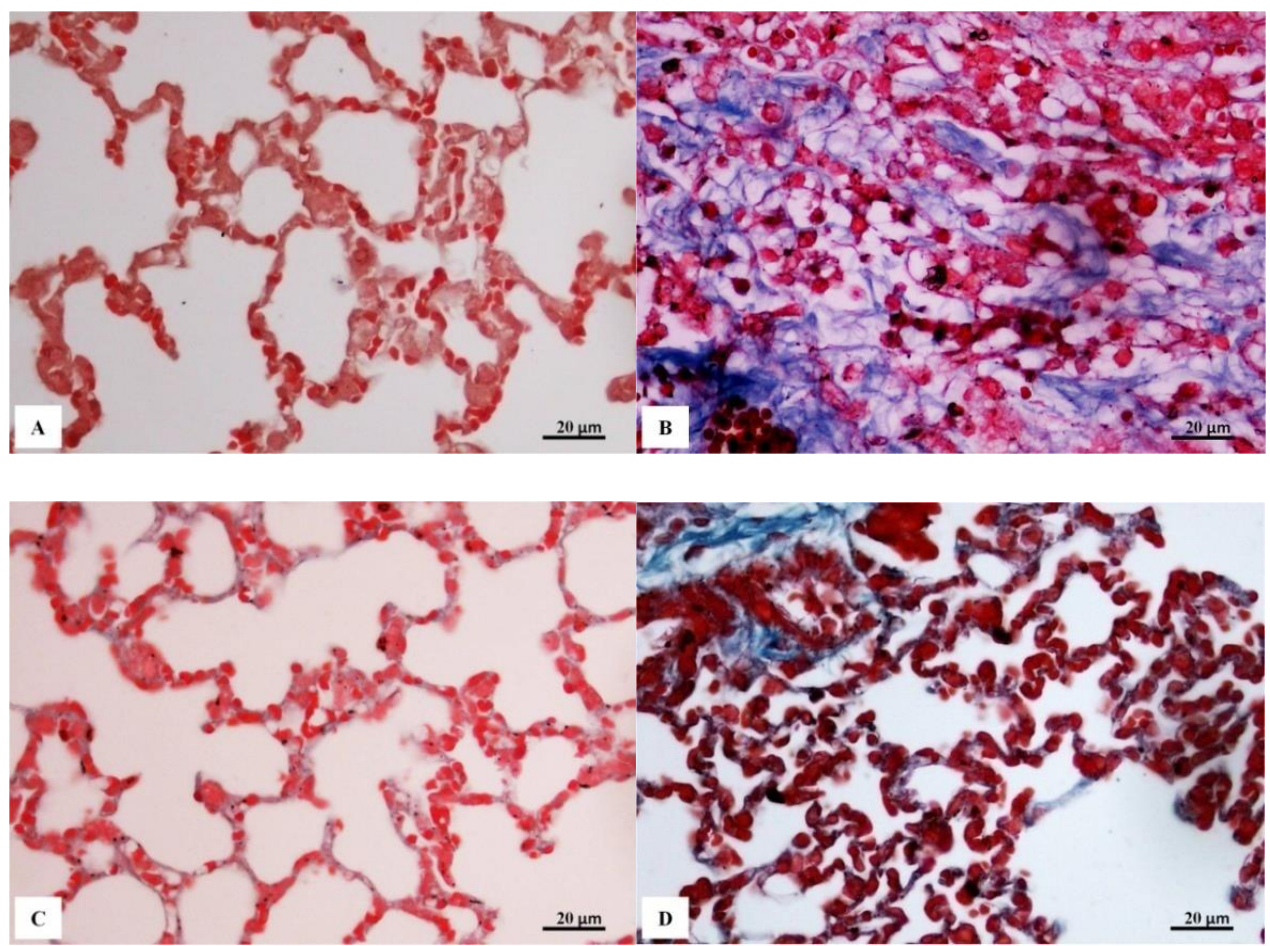

Figure 2. Photomicrography of lung tissues by MT staining of each treatment group: Control (A); BLM (B); CMN (C); $\mathrm{BLM}+\mathrm{CMN}(\mathrm{D})$ 
Yamamoto \& Nishioka (2000) said that in mice everyday induced by BLM SC for 4 weeks, there was pulmonary fibrosis characterized by mononuclear cell infiltration, ederma, and septum alveolar thickening due to decrease in number of macrophages alveolar and lymphocyte. Besides, Izbicki et al. (2002) found that there were perivascular and lymphocytes peribronkial (day 3), subcapsular fibrosis (day 6), and decreasing in number of macrophages alveolar and septum alveolar (day 14) in mice's lung histology induced by pulmonary fibrosis with single dose BLM by intratracheal.

\section{Histology result by Masson's Trichrome (MT) staining}

Tissue staining techniques by MT is addressed to identify the presence of the connective tissue or collagen in the tissue. Result of the lung tissue staining by MT technique was presented in Figure 2.

Figure 2A (control) and $2 \mathrm{C}(\mathrm{CMN})$ shows normal structure of lung tissues with thin alveoli wall $(3.7 \pm 0.6$ $\mu \mathrm{m})$. In the two figures do not show an excessive blue structure, indicating that in the two group there is no excessive collagen accumulation. On the contrary, figure 2B (BLM) shows blue accumulation which extends almost to the entire visual field. The blue color on lung slide colored by MT indicating the presence of accumulation connective tissue or collagen (Suvik \& Effendy 2013). Besides, in the BLM group was also seen smaller alveoli diameter compared to the control group. Figure 2D (BLM+CMN) shows light accumulation of collagen visualized by blue color and looked like thickening of the alveoli wall.

\section{Width of connective tissue}

Measurement of connective tissue width in the lung was done to determine extent of lung tissue damage due to BLM application. In figure 3 , it is not seen the presence of a significant differences of the connective tissue between control group $(2.4 \pm 0.8 \%)$ and CMN group $(1.5 \pm 0.6 \%)$. However, in BLM group $(15.0 \pm 2.4 \%)$, there was significantly wider connective tissue value $(\mathrm{P}<0.05)$ compared to control group. In the BLM+CMN group $(6.2 \pm 2.0 \%)$, there was significantly lesser width connective tissue $(\mathrm{P}<0.05)$ compared to the BLM group. This research result was in line with Izbicki et al. (2002) that there was an increase in connective tissue width of mice lung induced by single dose Bleomycin by intratracheal. Besides, Liu et al. (2013) also reported that there were an inflammation and fibrosis in interstitial of mice lung tissue induced by BLM through intratracheal.

Wide development of connective tissue in BLM group was caused by BLM activity which may induce pulmonary fibrosis by causing inflammation, than it developed become proliferation of fibroblast. Fibroblast is a cell which produced extracellular matrix (Todd et al. 2012). Yamamoto \& Katayama (2011) said that BLM can stimulate endothelia cell, macrophage, and fibroblast to induce inflammatory mediator. The inflammatory mediator will induce proinflammatory cytokines, cytokine fibrogenic, transforming growth factor- $\beta$ (TGF- $\beta$ ), apoptosis, and the release of free radicals.

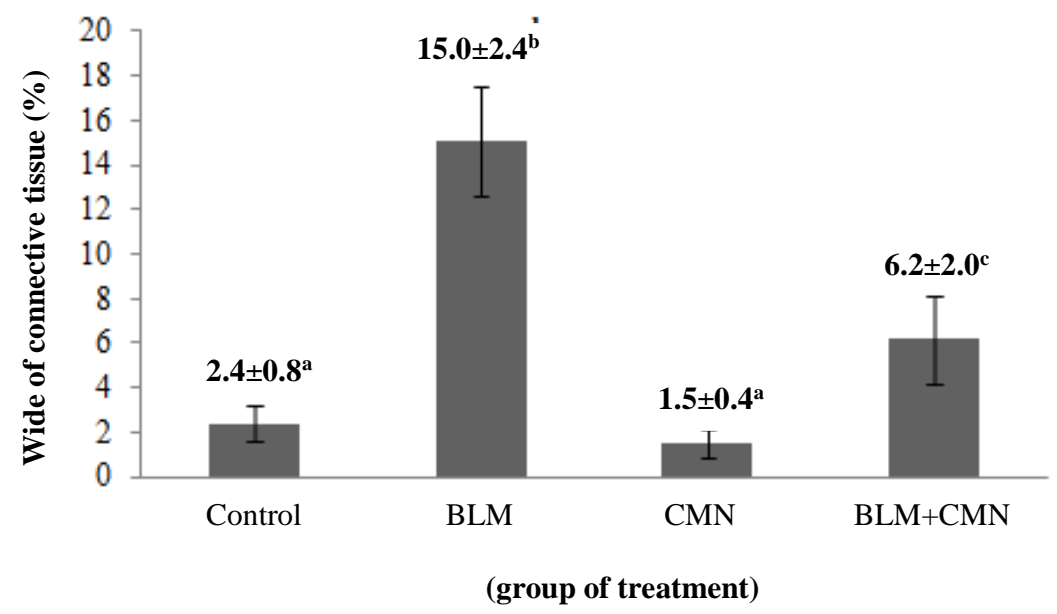

Figure 3. The wide of connective tissue of each treatment group, different superscript word shows significant difference $(\mathrm{P}<0.05)$ 
Reinert et al. (2013) reported that low BLMhydrolase enzyme activity can be a predisposing factor of pulmonary fibrosis due to the BLM application. Through in vivo, the BLM will be metabolized become non-toxic molecule with Bleomycin-hydrolase enzyme help (Haston et al. 2002). This enzyme is cytosolic aminopeptidase group which has low activity in lung and skin (Reinert et al. 2013). Therefore, BLM application may cause the pulmonary fibrosis. The fibrosis in the lung is started by an inflammatory. The inflammatory will develop into proliferation of fibroblasts into myofibroblast (cell produces collagen), and it finished by persistent formation of connective tissue. Mechanism of fibrosis induction by BLM was caused by increasing secretion of extracellular matrix proteins because of cytokine fibrogenic effect which was released by macrophages, endothelial cells, and fibroblasts (Reinert et al. 2013). Besides, BLM in the cells will bind with iron ion $\left(\mathrm{Fe}^{+2}\right)$ and oxygen forming $\mathrm{Fe}^{+3}$ ion which produce the free radicals, so that cause DNA damage, RNA degradation, and inducing the apoptosis (Yamamoto 2010). Moreover, the free radicals or reactive oxygen species can produce direct toxicity through participation in redox reactions and subsequent fatty acid oxidation, which leads to membrane instability. Oxidant can cause inflammatory reaction within be lung. The inflammatory mediators like cytokines such as interleukin-1, macrophage inflammatory protein-1, platelet-derived growth factor, and TGF- $\beta$ are released from alveolar macrophages in animal models of bleomycin toxicity, resulting in fibrosis. Damage and activation of alveolar epithelial cells may result in the release of cytokines and growth factors that slimulate proliferation of myofibroblast and secretion of pathologic extracellular matrix, leading to fibrosis.

The inflammation due to BLM application will cause body to response to repair the tissue by involving connective tissue reconstitution from the fibroblast into myofibroblast (Reinert et al. 2012). Myofibroblast is the main component in fibrosis process or wound healing. This myofibriblast will produce extracellular matrix, so it will cause extracellular matrix proteins accumulation. Previous study conducted by Xu et al. (2009) showed that TGF- $\beta$ is cytokine inducer of differentiation of fibroblast cell into myofibroblast cell. Yamamoto \& Nishioka (2004) presented that several actions of TGF$\beta$ are, among other as chemotactic macrophages and fibroblasts, stimulating fibroblast proliferation, increasing extracellular matrix synthesis, decreasing extracellular matrix proteinase regulation, and increasing proteinase inhibitor regulation. So that exacerbates the development of fibrotic lesions in the lung.

The opposite occurred in BLM+CMN group where there was a significant decrease $(\mathrm{P}<0.05)$ of width of connective tissue compared to the BLM group (Figure 3). In line with Punithavathi et al. (2000) that there was a decreasing of alveolar macrophage amount, superoxide and nitrikoksida in rats given oral curcumin treatment after single dose Bleomycin induction by intratracheal. So, in his research, it was concluded that curcumin was a potential material as an antiinflammatory and anti-fibrogenic in BLM-induced pulmonary fibrosis.

Bleomycin as an antibiotic antitumor agent, widely used for livestocks, such as pig (Balazs et al. 1994) and sheep (Organ et al. 2015). Same as in laboratory animals, BLM utilization in pig and sheep also caused side effect such as an inflammation into pulmonary fibrosis (Balazs et al. 1994; Organ et al. 2015). Pathogenesis mechanism of pulmonary fibrosis due to BLM application in livestocks was alike with the laboratory animals, so that was possible to be given curcumin as anti-inflammation and antioxidant to reduce fibrogenesis severity in the pulmonary fibrosis cases due to BLM application.

The decreasing of width of lung connective tissue in this study may be caused by 2 factors. First, the curcumin can directly inactivate the bleocymin activity, so that inflammation did not occur. Second, activity of anti-inflammation from the curcumin causes the inflammation become lower, so that fibrosis can be pressed. The second one is closer with pathogenesis of fibrosis inhibition by the curcumin. This was caused by BLM induction and curcumin therapy conducted through 2 different ways. Bleomycin induction was done subcutaneously, whereas curcumin therapy was done by intraperitoneal. Both of subcutaneous and intraperitoneal ways will interact systematically in the body, so that increasing width of lung connective tissue due to Bleomycin application possibly hampered by anti-inflammation activity from the curcumin. Besides, the curcumin was known to have effectiveness as an inhibitor receptor TGF- $\beta$, so that TGF- $\beta$ production can be inhibited (Mo et al. 2012).

Prasad et al. (2014) said intraperitonel injection of curcumin more often applied to animals than to human. Besides, the bioavailability compound of curcumin via intraperitoneal injection is higher than gavage. Interestingly, oral curcumin treatment showed no effect on important measure of BLM-induced injury in mice, whereas intraperitoneal curcumin administration effectively inhibited inflammation and collagen deposition along with a trend toward improved survival of animal, and also reduced fibrotic progression even when administered after the acute bleomycin-induced inflammation had subsided (Smith et al. 2010).

Smith et al (2010) said that curcumin administration could significantly prevent lung inflammation and collagen deposition in pulmonary fibrosis induced by BLM by intratracheal. Curcumin was high pleiotropic 
molecule which able to interact and bind with the most of inflammation molecule target (Jurenka 2009; Marçal et al. 2012). Curcumin has been reported having activity as an anti-cancer (Wiken et al. 2011), anti-oxidant (Bhullar et al. 2013) and anti-inflammation (Basnet \& Skalko-Basnet 2011). Turmeric bioactive compounds had protective effect to heart cell which exposed to toxic chemicals such as tetrachloride $\left(\mathrm{CCl}_{4}\right)$ (Prakash et al. 2008; Kardena \& Winaya 2011). Yu et al. (2011) reported that curcumin administration can reduce pancreatic tissue damage and another organs due to caerulein induction through inhibiting the release of inflammatory mediator of TNF- $\alpha$ cytokines.

Curcumin has been reported to exhibit antitumorigenic and chemo-preventive activities due to the structural resemblance of dibenzoyilmethane (DBM) to the anti-inflammatory and aspirin-like skeleton of DBM derivates (Lin et al. 2011). Villegas et al. (2011) reported curcumin has also demonstrated protective and preventive effect in progression of colorectal colitis cancer, which was collerated with a lowered immunereactivity of beta-catenin and reduction of proinflammatory cytokine levels and a decrease of inflammatory mediator's overexpression.

Lee et al. (2010) evaluated that curcumin as a potential dietary supplement in the setting of thoracic radiotherapy in mice with creating a baseline radioprotective state prior to irradiation by inducing protective gene expression as well as having potent direct antioxidant scavenging activity. Li et al. (2013) said curcumin application has a protective effect on the acute hepatic injury induced by acetaminophen with reduced acetaminophen-induced hepatocyte apoptosis and that protection may be related to its inhibition of lipid peroxidation and oxidative stress.

\section{Thickness of alveolar wall}

Figure 4 shows that there is no significant difference of alveolar wall between control group $(3.7 \pm 0.6 \mu \mathrm{m})$ and $\mathrm{CMN}$ group $(3.4 \pm 0.5 \mu \mathrm{m})$. However, there was significantly $(\mathrm{P}<0.05)$ higher alveolar wall thickness value in BLM group $(24.9 \pm 6.3 \mu \mathrm{m})$ compared to the control group. In BLM+CMN group $(9.9 \pm 2.6 \mu \mathrm{m})$ there was significantly $(\mathrm{P}<0.05)$ lower alveolar wall thickness value compared to BLM group.

The results about width of connective tissue and alveolar wall thickness in each treatment group were presented in Table 1.

This research result is aligned with a research of Izbicki et al. (2002) where alveolar wall thickening in mice lung tissue induced by single dose BLM by intratracheal. Alveolar wall thickening in BLM group

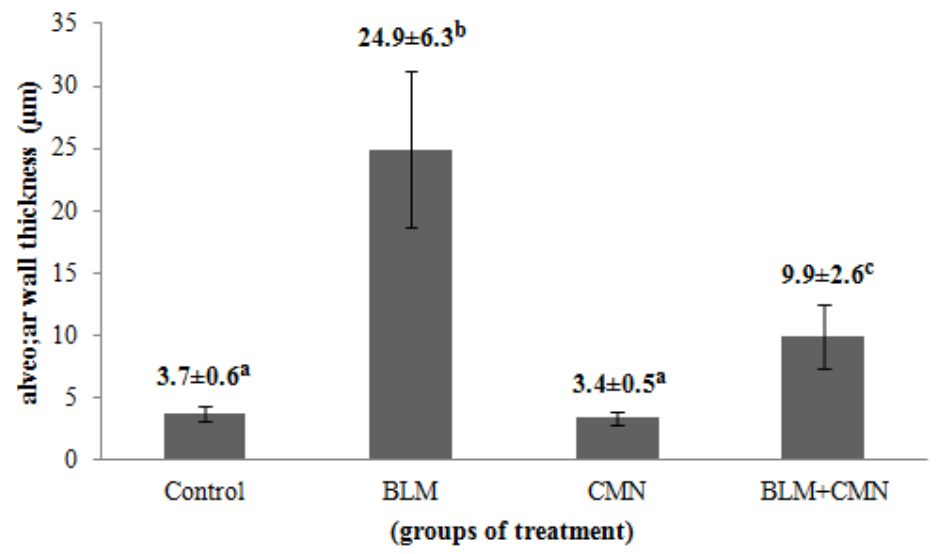

Figure 4. The Alveolar wall thickness in each treatment group, different superscript word shows significantly $(\mathrm{P}<0.05)$ difference

Table 1. Result of the wide of connective tissue and alveolar wall thickness

\begin{tabular}{lcc}
\hline \hline Treatment Group & Wide of connective tissue $(\%)$ & Alveolar wall thickness $(\mu \mathrm{m})$ \\
\hline Kontrol & $2.39 \pm 0.78^{\mathrm{a}}$ & $3.72 \pm 0.56^{\mathrm{a}}$ \\
BLM & $15.03 \pm 2.45^{\mathrm{b}}$ & $24.93 \pm 6.26^{\mathrm{b}}$ \\
CMN & $1.50 \pm 0.61^{\mathrm{a}}$ & $3.39 \pm 0.54^{\mathrm{a}}$ \\
BLM+CMN & $6.17 \pm 2.01^{\mathrm{c}}$ & $9.95 \pm 2.60^{\mathrm{c}}$ \\
\hline
\end{tabular}

Different superscript in one same column shows significantly difference $(\mathrm{P}<0.05) \mathrm{n}=4$ 
was caused by BLM administration continuously every day, which eventually caused chronic type lesio forming. The BLM continuous administration caused formation of progressive pulmonary fibrosis lesion (Schwaiblmair et al. 2012; Reinert et al. 2013). Increase wall thickness was caused by the existence of the fibrosis, besides it can also caused by interstitial edema (Izbicki et al. 2002).

In this study, Bleomycin toxicity was caused by low activity of BLM-hydrolase enzyme in the lung causing the BLM not metabolized into intoxic molecule form. Reinert et al. (2013) said that low activity of BLMhydrolase enzyme in the lung resulted in an excessive apoptosis. Besides, the BLM can also stimulate endothelial cell, macrophage, and fibroblast to induce inflammatory mediator, apoptosis, and free radicals (Yamamoto \& Katayama 2011). The most common symptomps from bleomycin-induced hypersensitivity pneumonitis are exertional dispnea and non-productive cough, with progressive pneumonitis dyspnea at rest, tachypnea, and cyanosis may occur (Sleijfer 2001).

Bleomycin is one of xenobiotis which able to induce radical oxygen synthesis excessively such as superoxide, hydrogen peroxide, peroxynitrite and hydroxyl radicals which is the mean mediator in inflammatory process in the lung (Oury et al. 2001). The inflammation will cause inflammatory cells entering the tissue and releasing cytokine inflammation mediator (Reinert et al. 2013). Furthermore, the cytokine caused fibroblast proliferation into myofibroblast. This inflammation and fibroblast proliferation will cause an increase of alveolar wall thickness to the pulmonary fibrosis (Izbicki et al. 2002).

Curcumin administration significantly press alveolar wall thickness incidence. The curcumin can press apoptosis and inflammation incidence; this is related to its activity as anti-oxidant and anti-inflammation (Smith et al. 2010; Bhullar et al. 2013; Basnet \& Skalko-Basnet 2011). Smith et al. (2010) presented that curcumin administration significantly press pulmonary inflammation and collagen deposition in the pulmonary fibrosis induced by BLM. Punithavathi et al. (2000) said that the curcumin mediated the reduction of total number of broncho-association limfoid follicles (BALF) cell by preventing inflammatory cell crossing endotel and epithelial basal membrane towards the inflammation location. This is because of the curcumin stabilized the endotel and epithelial basal membrane. Therefore, the curcumin activity as anti-oxidant and anti-inflammation can press alveolar wall thickness incidence in the lung due to BLM administration.

\section{CONCLUSION}

Curcumin administration can inhibit fibrogenesis in mice pulmonary fibrosis due to the BLM application. This information can be used as first information to prevent side effect of BLM utilization to cancer patients who has to undergo chemotherapy.

\section{ACKNOWLEDGEMENT}

This research was supported by lecturer and pathology staffs, clinical department, reproduction, and pathology FKH-IPB.

\section{REFERENCE}

[AVMA] American Veterinary Medical Association. 2013. AVMA guidelines for the euthanasia of animals: 2013 edition. Version 2013.0.1. [accessed 2/1/2015]. https://www.avma.org/KB/Policies/Documents/euthanas ia.pdf.

Balazs G, Noma S, Khan A, Eacobacci T, Herman PG. 1994. Bleomycin-induced fibrosis in pig: evaluation with CT. Radiology. 191:269-272. http://dx.doi.org/10.1148/ radiology.191.1.7510895.

Basnet P, Skalko-Basnet N. 2011. Curcumin: an antiinflammatory molecule from a curry spice on the path to cancer treatment. Molecules. 16:4567-4598. http://dx.doi.org/10.3390/molecules16064567.

Beevers CS, Huang S. 2011. Pharmacological and clinical properties of curcumin. Botanics: Targets Therapy. 1:15-18.

Bhullar KS, Jha A, Youssef D, Rupasinghe HPV. 2013. Curcumin and its carbocyclic analogs: structure-activity in relation to antioxidant and selected biological properties. Molecules. 18:5389-5404. http://dx.doi.org/ 10.3390/molecules 18055389 .

Brugge SS, Claasen HR, Dawson L. 2013. Drug induced lung injury- a case of fatal Bleomycin interstitial pneumonitis. Netherlands J Critical Care. 17:25-29.

Chu E, Harrold LJ, Tiedemann D, Copur MS. 2010. Chemotherapeutic and biologic drugs. In: Chu E, DeVita VT, editors. Physicians' cancer chemotheraphy drug manual. USA: Jones and Bartlett Publishers. p. 5154.

Fischer AH, Jacobson KA, Rose J, Zeller R. 2006. Preparation of cells and tissues for fluorescence microscopy. In: Spector DL, Goldman RD, editors. Basic methods in microscopy. USA: Cold Spring Harbor Laboratory Press. 
Frusch N, Servais S, De Prijck B, Corhay JL, Beguin Y, Louis R, Duysinx B. 2012. Spontaneous pneumomediastinum caused by Bleomycin-induced pneumonitis. Acta Clin Belgi. 67:370-371. http://dx.doi.org/10.2143/ACB.67.5. 2062693.

Haston CK, Wang M, Dejournett RE, Zhou X, Ni D, Gu X, King TM, Well MW, Newman RA, Amos CI, Travis EL. 2002. Bleomycin hydrolase and a genetic locus within the MHC effect risk for pulmonary fibrosis in mice. Hum Mol Gen. 11:1855-1863.

Izbicki G, Segel MJ, Christensen TG, Conner MW, Breuer R. 2002. Time course of Bleomycin-induced lung fibrosis. Int J Exp Path. 83:111-119.

Juniantito $\mathrm{V}$, Izawa $\mathrm{T}$, Yuasa $\mathrm{T}$, Ichikawa $\mathrm{C}$, Yano $\mathrm{R}$, Kuwamura M, Yamate J. 2013. Immunophenotypical characterization of macrophages in rat Bleomycininduced scleroderma. Vet Pathol. 50:76-85.

Jurenka JS. 2009. Anti-inflammatory properties of curcumin, a major constituent of Curcuma longa: a review of preclinical and clinical research. Alter Med Rev. 14:141-153.

Kardena IM, Winaya IBO. 2011. Kadar perasan kunyit yang efektif memperbaiki kerusakan hati mencit yang dipicu karbon tetraclorida. J Vet. 12:34-39.

Lee JC, Kinniry PA, Arguiri E, Setora M, Kanterakis S, Chatterjee S, Solomides CC, Javvadi P, Koumenis C, Cengel KA, Chistofidou-Solomidou M. 2010. Dietary curcumin increase antioxidant defenses in lung, ameliorates radiation-induced pulmonary fibrosis, and improves survival in mice. Radiat Res. 173:590-601. http://dx.doi.org/10.1667/RR1522.1.

Ley B, Collard HR. 2013. Epidemiology of idiopathic pulmonary fibrosis. Clin Epid. 5:483-492.

Li G, Chen J, Wang C, Xu Z, Nie H, Qin X, Chen X, Gong Q. 2013. Curcumin protects against acetaminopheninduced apoptosis in hepatic injury. World $\mathrm{J}$ Gastroentero. 19:7440-7446. http://dx.doi.org/10.3748/ wjg.v19.i42.7440.

Lin CC, Liu Y, Ho CT, Huang MT. 2011. Inhibitory effects of 1,3-bis-(2-substituted-phenyl)-propane-1,3-dione, $\quad \beta$ diketone structural analogues of curcumin, on chemicalinduced tumor promotion and inflammation in mouse skin. Food Func. 2:78-83. http://dx.doi.org/10.1039/ c0fo0098a.

Liu W, Wan J, Han J, Li C, Feng D, Yue S, Huang Y, Chen Y, Cheng Q, Li Y, Luo Z. 2013. Antiflammin-1 attenuates Bleomycin-induced pulmonary fibrosis in mice. Respir Res. 14:101-111.

Loomis-King H, Flaherty KR, Moore BB. 2013. Pathogenesis, current treatments and future directions for idiopathic pulmonary fibrosis. Curr Opin Pharmacol. 13:377-385. http://dx.doi.org/10.1016/j.coph.2013.03.015.

Marçal H, Wanandy N, Castellano-Gonzales G, Braidy N, Guillemin GJ. 2012. Curcumin: medical properties, molecular targets, and biological mechanism. In: Sasaki J, Kichida M, editors. Curcumin: biosynthesis, medical uses and health benefits. Sydney (Australia): Nova Science Publishers.

Matsushita M, Toshiyuki Y, Yokozeki H. 2008. Role of cytokines and proteases in murine scleroderma. J Med Dent Sci. 55:215-225.

Mo N, Li Z, Li J, Cao Y. 2012. Curcumin inhibits TGF- $\beta 1$ induced MMP-9 and invasion through ERK and smad signaling in breast cancer MDA-MB-231 cell. Asian Pasific J Cancer Prev. 13:5709-5714. http://dx.doi.org/10.3714/APJCP.2012.13.11.5709.

Organ L, Bacci B, Koumoundouros E, Barcham G, Kimpton W, Nowell CJ, Samuel C, Snibson K. 2015. A novel segmental challenge model for Bleomycin-induced pulmonary fibrosis in sheep. Exp Lung Res. 41:115134. http://dx.doi.org/10.3109/01902148.2014.985806.

Oury TD, Thakker K, Menache M, Chang LY, Crapo JD, Day BJ. 2001. Attenuation of Bleomycin-induced pulmonary fibrosis by a catalytic antioxidant metalloporphyrin. Am J Respir Cell Mol Biol. 25:164-169.

Prakash O, Singh GN, Singh RM, Mathur SC, Bajpai M, Yadaf S. 2008. Protective effect on a herbal formula against carbon tetrachloride induced hepatotoxicity. Int J Pharm. 4:282-286.

Punithavathi D, Venkatesan N, Babu M. 2000. Curcumin inhibition of bleomycin-induced pulmonary fibrosis in rats. British J Pharm. 131:169-172.

Reinert T, Serodia da Rocha Baldotto C, Nunes FAP, Alves de Souza-Scheliga A. 2013. Bleomycin-induced lung injury. J Cancer Res. http://dx.doi.org/10.1155/2013/ 480608 .

Schwaiblmair M, Behr W, Haeckel T, Märkl B, Foerg W, Berghaus T. 2012. Drug induced interstitial lung disease. Respir Med J. 6:63-74.

Sleijfer S. 2001. Bleomycin-induced pneumonitis. Chest. 120:617-624

Smith MR, Ganggireddy SR, Narala VR, Hogaboam CM, Standiford TJ, Christensen PJ, Kondapi AK, Reddy RC. 2010. Curcumin inhibits fibrosis-related effects in IPF fibroblast and in mice following Bleomycin-induced lung injury. Am J Physiol Lung Cell Mol Physiol. 298:616-625.

Smith MR, GangireddySR, Narala VR, Hogaboam CM, Standiford TJ, Christensen PJ. 2010. Curcumin inhibit fibrosis-related effects in IPF fibroblasts and in mice following bleomycine-induced lung injury. Am J Physiol Lung Cell Mol Physiol. 298:L616-625.

Suvik A, Effendy AWM. 2012. The use of modified Masson's trichrome staining in collagen evaluation in wound healing study. Malay J Vet Res. 3:39-47.

Todd N, Luzina IG, Atamas SP. 2012. Molecular and cellular mechanism of pulmonary fibrosis. J Fibrogen Tissue Repair. 5:11-35.

Villegas I, Sánchez-Fidalgo S, de la Lastra CA. 2011. Chemopreventive effect of dietary curcumin on inflammation-induced colorectal carcinogenesis in 
mice. Mol Nutr Food Res. 55:259-267. http://dx.doi.org/ 10.1002/mnfr.201000225.

Wilken R, Veena MS, Wang MB, Srivatsan ES. 2011. Curcumin: a review of anti-cancer properties and therapeutic activity in head and neck squamous cell carcinoma. Mol Cancer. 10:1-19.

Xu J, Lamouille S, Derynck R. 2009. TGF-beta-induced epithelial to mesenchymal transition. Cell Res. 19:156172.

Yamamoto T, Katayama I. 2011. Vascular changes in Bleomycin-induced scleroderma. Int $\mathrm{J}$ Rheumatol. http://dx.doi.org/10.1155/2011/270938.

Yamamoto T, Nishioka K. 2000. Animal model of sclerotic skin: III: Histopathological comparison of Bleomycininduced scleroderma in various mice strains. Arch Dermatol Res. 292:535-541.
Yamamoto T, Nishioka K. 2004. Possible role of apoptosis in the pathogenesis of Bleomycin-induced scleroderma. J Invest Dermatol. 122:44-50.

Yamamoto T. 2010. Animal model of systemic sclerosis. J Dermatol. 37:26-41.

Yu W, Xu G, Ren G, Xu X, Yuan H, Qi X, Tian K. 2011. Preventive action of curcumin in experimental acute pancreatitis in mouse. Indian J Med Res. 134:717-724.

Zhang D, Huang C, Yang C, Liu RJ, Wang J, Niu J, BrÖmme D. 2011. Antifibrotic effects of curcumin are associated with overexpression of cathepsins $\mathrm{K}$ and $\mathrm{L}$ in bleomysin treated mice and human fibroblast. Resp Res. 12:154166. 